Harnanti et al., Afr., J. Infect. Dis. (2018) 12(S): 83-89

https://doi.org/10.2101/Ajid.v12i1S.12

\title{
CONCOMITANT SEXUALLY TRANSMITTED DISEASES IN PATIENTS WITH DIAGNOSED HIV/AIDS: A RETROSPECTIVE STUDY
}

\section{Densy Violina Harnanti ${ }^{1}$, Afif Nurul Hidayati ${ }^{1}$, Muhammad Miftahussurur ${ }^{2}$}

${ }^{1}$ Department of Dermatology and Venereology, Faculty of Medicine, Universitas Airlangga/Dr. Soetomo General Hospital/Universitas Airlangga Hospital, Surabaya 60286, Indonesia; ${ }^{2}$ Department of Internal Medicine, Faculty of Medicine-Institute of Tropical Disease-Universitas Airlangga Hospital, Universitas Airlangga, Surabaya 60286, Indonesia.

*Corresponding Author E-mail: densy.violina1980@gmail.com

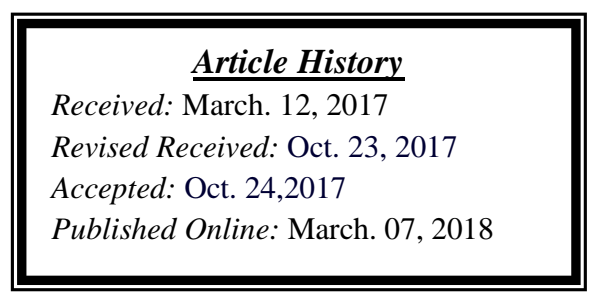

\section{Abstract}

Background: Human immunodeficiency virus (HIV) is a virus that causes Acquired Immunodeficiency Syndrome (AIDS) which weaken the human immune system and thus increasing the incidence of sexually transmitted infections (STIs) and vice versa.

Materials and Methods: A retrospective study of STIs in HIV/AIDS patients in Unit Perawatan Intermediate Penyakit Infeksi (UPIPI) Dr. Soetomo General Hospital Surabaya was conducted from January $1^{\text {st, }} 2013$ to December

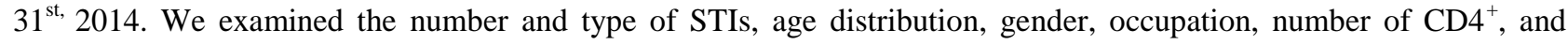
antiretroviral treatment of patients with HIV/AIDS. The data were presented in a descriptive analysis.

Results: The percentage of STIs patients was 4.2\% (148 of 3.350) of all patients with HIV/AIDS in the UPIPI Outpatient Clinic of Dr. Soetomo General Hospital. Most patients were 25-44 years old (70.9\%) including 54.7\% were males, $8.0 \%$ were housewives, and $1.4 \%$ were students. The five highest prevalence of STIs were condylomata acuminate $(43.9 \%)$, non-specific genital ulcers $(11.5 \%)$, syphilis $(10.7 \%)$, genital herpes $(10.1 \%)$, and scabies $(8.1 \%)$. The sexual predilections consisted of heterosexual $(70.9 \%)$, homosexual $(12.2 \%)$, bisexual (2.0\%), and no data (14.9\%). Patients with the number of $\mathrm{CD}^{+}<200 \mathrm{~mm}^{3}$ was $52.0 \%$ and $79.1 \%$ of the patients received ARV therapy. Conclusion: STIs and HIV/AIDS were closely related. HIV/AIDS could increase the incidence of STIs and STIs could elevate HIV/AIDS.

Keywords: Sexually Transmitted Infections, HIV/AIDS, Condylomata Acuminate, CD4

\section{Introduction}

Acquired Immunodeficiency Syndrome (AIDS) is a group of symptoms caused by infection with Human immunodeficiency virus (HIV) that affects the immune system (Bunker et al., 2010; Uihlein et al., 2012). Based on the report of the Directorate General of Disease Control and Environmental Health, Ministry of Health Republic of Indonesia, the prevalence of AIDS cases in Indonesia from 1987 to 2014 was 23.41/100,000 population (Kementrian Kesehatan Republik Indonesia, 2014). The virus infects CD4 ${ }^{+} \mathrm{T}$ cells and thus causes the weakening of a patient's immune system (Bunker et al., 2010). Sexual contact is one of the main ways of HIV transmission since the virus is most abundant in the semen, vaginal, and cervical discharge. Transmission of HIV infection through anal intercourse is more likely to happen because the rectal mucous membrane is thin and damaged easily (Nasronudin, 2014). There is a close relationship between STIs and HIV; the presence of STIs could increase the chance of acquiring and spreading HIV infection and so does the presence of HIV infection affects in STIs (Ochom et al., 2017; Tzeng et al., 2013; UNAIDS, 2012).

The life cycle of retroviruses resembles intracellular parasite which means HIV cannot replicate outside of human cells. Infection of HIV to the host cell starts with the binding of membrane surface protein and gp120 and the virus envelope protein (Moir et al., 2011). One of the membrane surface protein of the host cell is CD4 ${ }^{+}$protein. The number and distribution of these receptors in the host cells have been considered to be capable of limiting the susceptibility of the cells to HIV infection. Furthermore, the need of co-receptors in virus entry stage has been found. The co-receptors are CCR5 (CC chemokine receptor 5) and CXCR4 (CXC chemokine receptor 4) which contain a protein that could facilitate the binding of HIV in vitro (Moir et al., 2011; Xhilaga, 2016). After the gp120 of HIV binds 
with CD4 and other-receptors, there is a change in gp41 conformation caused by the entry of virus' peptide to the cytoplasm of the host cell (Xhilaga, 2016). The most common HIV is the one that binds to CCR5 (R5 strains), which infects macrophages and $\mathrm{T}$ cells and characterized by less aggressive growth in vitro. Other strain is the one that binds with CXCR4 (X4 strain), which specifically only infects T cells. Latest strategy to improve antiretroviral therapy is to develop an agent that capable of preventing HIV entry into host cells (Tzeng et al., 2013).

The decrease in the cellular immune system of HIV patients is characterized by the declining of $\mathrm{T}$ helper lymphocytes $\left(\mathrm{CD}^{+}\right)$in HIV patients. The patients will be prone to opportunistic diseases that caused by microorganisms such as viruses, fungi, and bacteria, while in normal circumstances, the body should be able to prevent the entry of such microorganism (Dewi et al., 2015), and STIs (Bunker et al., 2010; Quader et al., 2017). The clinical manifestations of STIs also become unspecific, where it tend to be more lesions with greater size than usual. It also tends to recur more often, or instead become persistent (Tzeng et al., 2013).

\section{Materials and Methods}

We used a retrospective descriptive as study design to determine the incidence, epidemiology, diagnosis, and treatment of STIs in patients with HIV/AIDS. The study populations were patients with HIV/AIDS in the UPIPI Outpatient Clinic Dr. Soetomo General Hospital during 2013-2014.The subject of the study were patients with HIV/AIDS that were diagnosed with STIs who fulfilled the inclusion and exclusion criteria. The inclusion criteria were all patients with HIV/AIDS that were diagnosed with new STI cases, and the exclusion criteria were all patients with HIV/AIDS with co-morbidities other than STIs. The diagnosis of HIV/AIDS was based on clinical manifestation supported by laboratory examination (Rapid test for HIV). In addition, the diagnosis of STIs was based on clinical manifestation and laboratory examination. Data were obtained from medical records of UPIPI Outpatient Clinic Dr. Soetomo General Hospital during 2013-2014. Data were evaluated descriptively, and the STIs in this study was just new cases. Ethical clearance of this study was given by the Research Ethics Committee of Dr. Soetomo General Hospital, Surabaya, Indonesia.

\section{Results}

There were a total of 3,550 patients with HIV/AIDS in UPIPI Outpatient Clinic of Dr. Soetomo General Hospital during 2013-2014, then 148 patients (4.2\%) who had STIs were selected. In 2014 the increased number of HIV/AIDS patients was accompanied by an increased number of patients with STIs. The number of HIV/AIDS patients in 2013 were 1,665 and $69(4.1 \%)$ of them had STIs. Meanwhile, in 2014, the number of patients with HIV/AIDS had increased to 1,885 and $79(4.2 \%)$ of them had STIs.

Most of the patients with HIV/AIDS and STIs in UPIPI outpatient clinic of Dr. Soetomo General Hospital during 2013-2014 were aged between 25-44 years old (70.9\%), with the youngest was 19 years old and the oldest was 73 years old. Male patients had a higher prevalence of having HIV/AIDS with STIs (81 patients, 54.7\%) compared to female patients (67 patients, $45.3 \%$ ). Based on the distribution of occupation, most of the patients worked in private sector, which was 40 patients (27\%), 28 patients were (18.8\%) unemployed, 12 patients $(8 \%)$ were housewives, 5 patients $(3.3 \%)$ were factory employees, 4 patients $(2.7 \%)$ were sales promotion girl, 3 patients $(2.0 \%)$ were the shopkeeper, 2 patients (1.4\%) were driver, 2 patients (1.4\%) were government employees, 2 patients (1.4\%) werehousekeepers, 2 patients $(1.4 \%)$ were farmers, 2 patients were marketing employees $(1.4 \%), 2$ patients were a student and scholar $(1.4 \%), 2$ patients were teachers $(1.4 \%), 1$ patient $(0.7 \%)$ was a soldier, 1 patient $(0.7 \%)$ was a salon employee, 1 patient $(0.7 \%)$ was an employee of local water companies, 1 patient $(0.7 \%)$ was a mechanic, 1 patient $(0.7 \%)$ was an architect; while 36 patients $(24.2 \%)$ had no data.

Based on the data above, the highest cases of STIs in HIV/AIDS patients were condylomata acuminate $(43.9 \%)$, non-specific genital ulcer $(11.5 \%)$, syphilis $(10.7 \%)$, genital herpes $(10.1 \%)$, and scabies $(8.1 \%)$. Another STIs were vulvovaginal candidiasis of 9 cases $(6.1 \%)$, non-specific genital infections (NSGIs) of 8 cases (5.4\%), chancroid of 2 cases $(1.4 \%)$, bacterial vaginosis, gonorrhoea urethritis, molluscum contangiosum and Bartholin cyst for each was 1 case $(0.7 \%)$.

The sexual predilection of the patients included heterosexual $(70.9 \%)$, homosexual (12.2\%) and bisexual (2.0\%), while $14.9 \%$ had no data. Based on the number of $\mathrm{CD}^{+}$, there were 148 patients with HIV/AIDS and STIs, 77 patients $(52.0 \%)$ had less than 200,30 patients $(20.3 \%)$ had $\mathrm{CD}^{+}$range from $200-350,14$ patients $(9.5 \%)$ had more than 350, whereas 27 patients $\left(18.2 \%\right.$ ) had no results of $\mathrm{CD}^{+}$count. On the other hand, there were 117 patients $(79.1 \%)$ who received therapy antiretroviral (ARV), while 31 patients $(20.9 \%)$ did not receive ARV therapy. Each patient might have received more than one treatment regarding their STIs.

Based on the treatment result, 61 patients $(41.2 \%)$ have not been cured who consisted of 48 patients $(32.3 \%)$ with condylomata acuminate, 3 patients $(2.1 \%)$ with non-specific genital ulcer, 2 patients $(1.4 \%)$ with scabies, 7 patients $(4.7 \%)$ with syphilis, 1 patient $(0.7 \%)$ with chancroid. There were four patients $(2.7 \%)$ who experienced recurrence by consisting of genital herpes in 1 patient $(0.7 \%)$, vulvovaginalis candidiasis in 2 patients $(1.3 \%)$, and condylomata acuminate in 1 patient $(0.7 \%)$. Seventy-five patients $(50.7 \%)$ were cured, and 8 patients $(5.4 \%)$ have no data. 


\section{Discussion}

The total number of patients who underwent treatment at UPIPI Outpatient Clinic Dr. Soetomo General Hospital during 2013-2014 were 3,550 patients. Then, from all of the HIV/AIDS patients, there were $148(4.2 \%)$ patients with STIs. The number of HIV/AIDS patients in 2013 was 1,665 and 69 (4.1\%) patients were diagnosed with STIs. Meanwhile, in 2014, the number of patients with HIV/AIDS had increased to 1,885 accompanied by an increase in patients who were diagnosed STIs to79 (4.2\%) patients. The relationship between STIs and HIV infection has not yet been fully understood. Some studies have proven that STIs could increase the risk of HIV and vice versa, the spread of HIV infection might also increase the prevalence and incidence of some STIs (Gap, 2015). In this study, the largest number from the age group of the HIV/AIDS patients with STIs were 105 patients (70.9\%) who aged 25-44 years old. It might be caused by the tendency of high sexual activity of people aged 25-44 years old. The data were consistent with studies conducted by Tzenget al. in 2013.

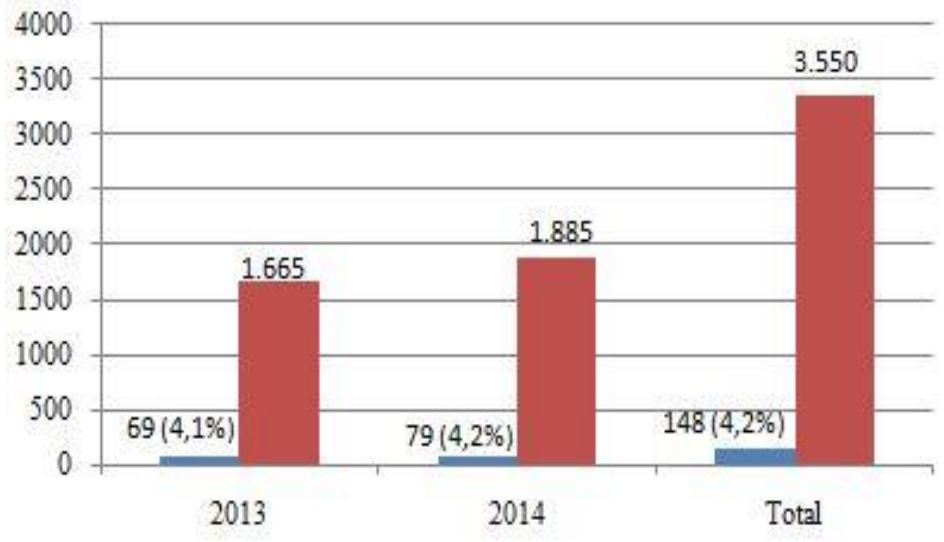

- Total STIs Patients with HIV/AIDS

\section{- Total HIV/AIDS Patients}

Figure1: The distribution of STIs patients with HIV/AIDS

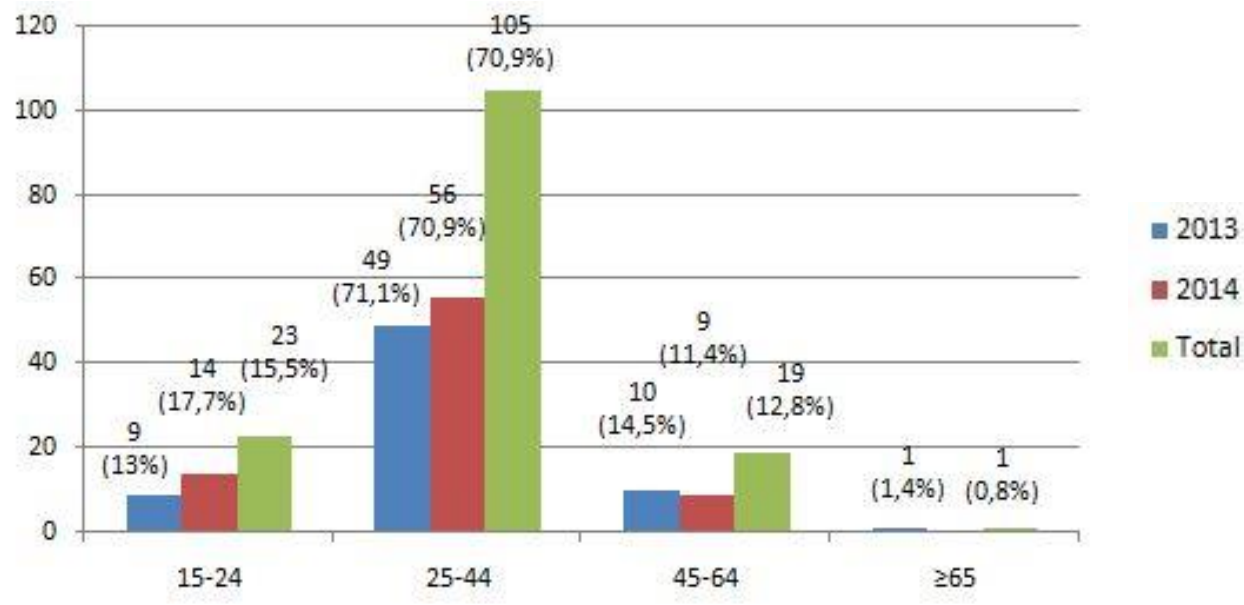

Figure 2: Age distribution of STIs patients with HIV/AIDS.

In this study, the majority of HIV/AIDS patients who experienced STIs were male. These results suggested that men might have more activities in outside, this might also lead to more exposure of risk factors compared to women. For example, working far from their house/family or even in different cities might force them to visit the prostitution. Other factors that might cause a higher number of STIs in male patients with HIV/AIDS was that some cases of STIs in women were asymptomatic. According to research data by Tzeng et al. in 2013, 97.4\% of patients with HIV/AIDS who have STIs were males (Tzeng et al., 2013).

Based on their occupation, most HIV/AIDS patients with STIs were private employees. The results of research in the Kariadi Hospital, Semarang, Indonesia in 2011 also showed that the highest percentage of patient occupation was private employees $21.43 \%$ (Nelwan et al., 2015). Regarding the distribution of STIs in HIV/AIDS patients, condylomata acuminate has the highest prevalence, which was 65 cases $(43.9 \%)$. The second highest was non-specific genital ulcers by 17 cases $(11.5 \%)$, followed by syphilis in 16 cases $(10.7 \%)$ and genital herpes in 15 cases $(10.1 \%)$. Scabies was found in 12 cases $(8.1 \%)$, whilst vulvovaginal candidiasis was found in 9 cases $(6.1 \%)$, non-specific genital infections (NSGIs) in 8 
cases (5.4\%), chancroid in 2 cases (1.4\%), while bacterial vaginosis, gonorrhea urethritis, molluscum contagiosum and Bartholin's cyst each was 1 case (0.7\%).The results were different from a previous study done by Tzeng et al. in 2013 which showed that the highest STI was Chlamydia (Tzeng et al., 2013). Chlamydia has symptoms that not typical and often regarded as a non-specific infection. The diagnosis of chlamydia also requires specific laboratory tests. Chun and his colleagues in 2013 said that there was a relationship between the numbers of HIV patients with increased HPV infection. The risk of being infected by HPV was increased 30 times in HIV patients with clinical manifestations of genital warts that develop into larger sizes and could be caused by multiple HPV sub-types. HPV infection in HIV patients also easily turn into cervical and anal cancers. The study also found that the incidence of HSV-infected patients increases in accordance with the increase of HIV infections (Chun et al., 2013). Most of HIV patients with HSV have manifestations of genital ulcers. Thus, the examination should be supported with genital ulcer history, physical examination and appropriate laboratory evaluation, because some STIs also has genital ulcer manifestations (Chun et al., 2013; Goff et al., 2014). Syphilis was the second most STIs in HIV patients also manifest as genital ulcers. Various studies have found an association between an increasing number of syphilis patients and the number of HIV patients. It was strongly associated with a decrease in the number of $\mathrm{CD}^{+}$which less than $200 \mathrm{~mm}^{3}$. HIV patients with a number of $\mathrm{CD}^{+}$less than $200 \mathrm{~mm}^{3}$ might have an increase in the incidences of syphilis. Some studies have found increased levels of $\mathrm{CD}^{+}$in patients after syphilis therapy (Chun et al., 2013).

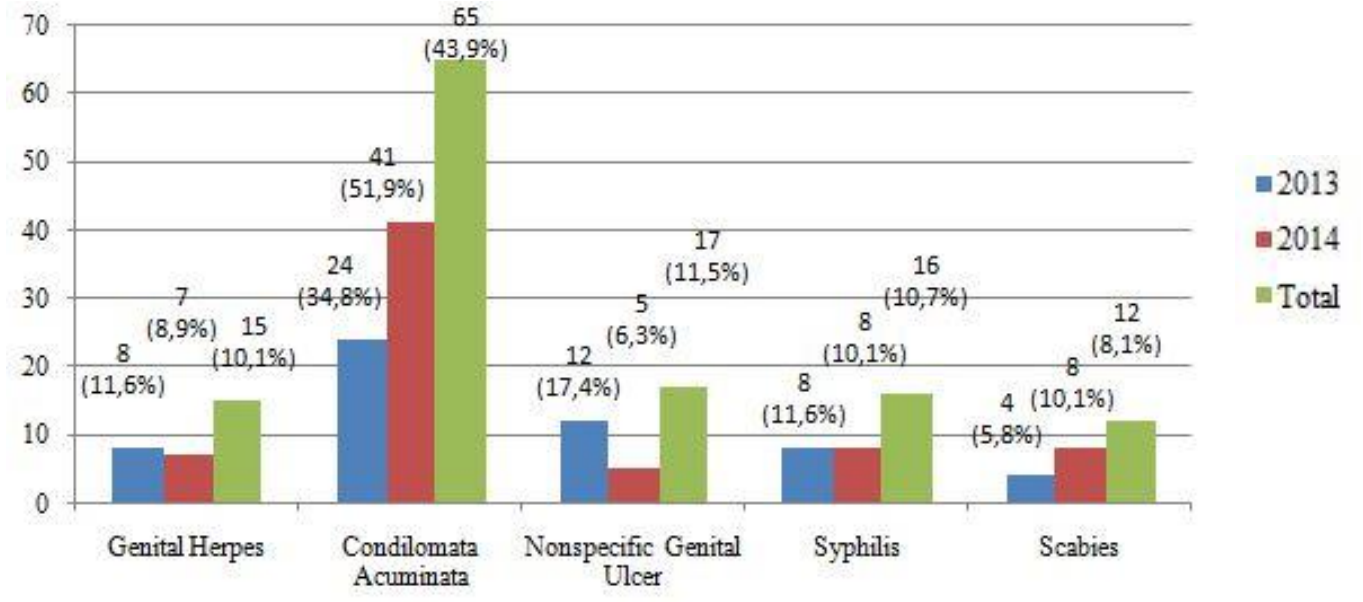

Figure 3: The five largest types of STIs in patients with HIV/AIDS

The results showed that most of the sexual predilection of the patients were heterosexual, followed by homosexual and bisexual. It might bedue to the STIs in women usually has been asymptomatic that might lead them to keep the tendency to switch partners so it increases transmission of STIs. According to Tzeng and his colleagues in 2013, most patients who have STIs were heterosexual (Tzeng et al., 2013). Hames and his colleagues said that homosexuality increased the risk of transmission of STIs, but most patients tended not to disclose their sexual behaviour (Hamish et al., 2016). Astindari's retrospective study on "How HIV/AIDS are Transmitted" were carried out in UPIPI during 2006-2010, and it was said that there was a change in the pattern of HIV transmission, which was originally highest by injecting drug users (IDUs) in 2005 became by heterosexual sexual intercourse in 2010. According to the Ministry of the Health Republic of Indonesia, the pattern of the spread of HIV/AIDS in Indonesia is also changing. In early of 1987, most of HIV transmissions were through heterosexual sexual intercourse. Along with the increase in IDUs in Indonesia since 1999 then the modes of transmission of HIV/AIDS were also shifted to IDUs. It was due to the reuse of needles that could increase the risk of disease transmission. Since 2008, the pattern of transmission of HIV/AIDS has shifted back to heterosexual sexual intercourse (Astindari et al., 2011). Also in Dr. Soetomo General Hospital, since 2006-2010 it was found a mode of transmission mainly through heterosexual intercourse. In male patients, a shift of mode of transmission of drug use to heterosexual sexual intercourse happened since 2008, and the mode of transmission through IDUs continues to drop since 2008. The decrease was due to the increase of awareness to not reuse needles amongst IDUs. But we need to be aware of transmissions in low-risk populations and the increase of STIs prevalence through sexual transmission (Astindari et al., 2011, Kementrian Kesehatan Republik Indonesia, 2014). Perinatal transmission was increasing in 2006 from 5 people $(1.3 \%)$ to $24(3.4 \%)$ in 2010, that showed more cases of infants acquiring HIV infection from their mothers. Therefore, prevention of perinatal transmission needs to be done, such as early diagnosis of HIV infection in pregnant women to maximize treatment options in pregnancy and optimize the time of therapy, planning birth by cesarean section, and breastfeeding planning. That will affect efforts to prevent the spread of HIV/AIDS. Additionally, we need to be aware of the possibility of increased cases of STIs (Abdulai et al., 2017; Astindari et al., 2011). 


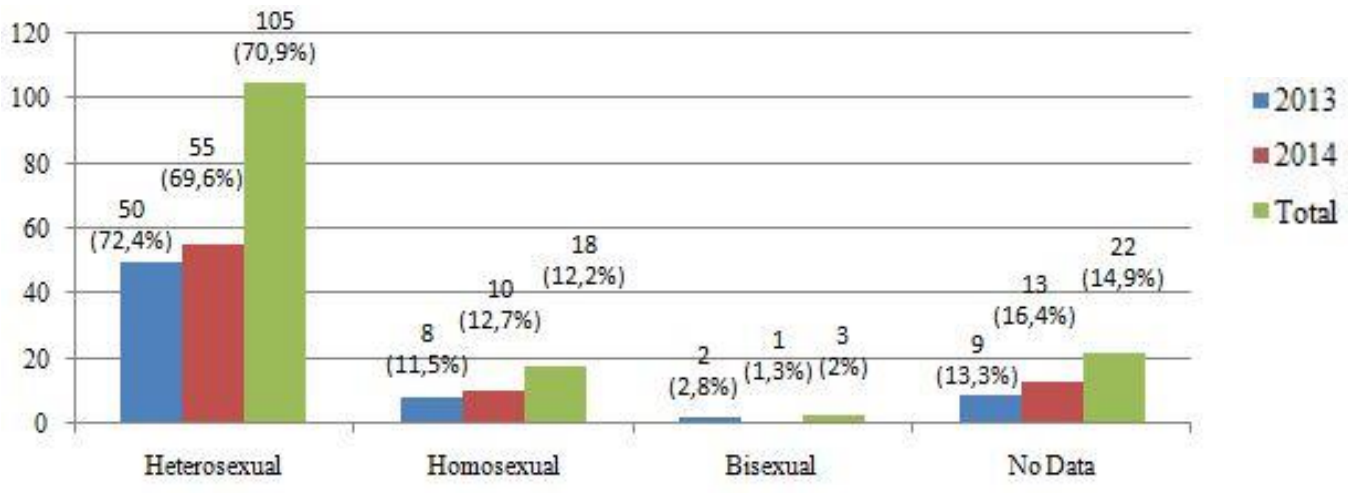

Figure 4: The sexual partner distribution of STIs patients withHIV/AIDS

There was a close relationship between the low number of $\mathrm{CD}^{+}{ }^{+}$with the increasing incidence of STIs (Furtado et al., 1999; UNICEF, 2012). Syphilis infection in HIV patients was associated with increased viral load and decreased of the $\mathrm{CD}^{+}$count. The increasing of viral load occurs mainly in patients with secondary syphilis infection. In a study of 76 participants, $33.3 \%$ showed an increase in viral load during syphilis infection. Forty-four patients had an overall viral load suppression before they were diagnosed with syphilis and eleven (25\%) of them showed a detectable viral load after they got infected. Nonetheless, the only confirmed factor associated with increased viral load was the absence of ART. It was also discovered that there a significant decrease in $\mathrm{CD} 4{ }^{+}$count in patients who recently got infected with syphilis compared to $\mathrm{CD} 4^{+}$count before the infection. The study also showed the decrease of the $\mathrm{CD} 4^{+}$count in 76 patients when compared to between before and during the syphilis infection $(590: 496 ; \mathrm{p}=0.0001)$. Moreover, 94 patients with syphilis infection showed the increase of the $\mathrm{CD}^{+}$count after they were treated (509:597; p=0.0001) (Buchacz et al., 2004).

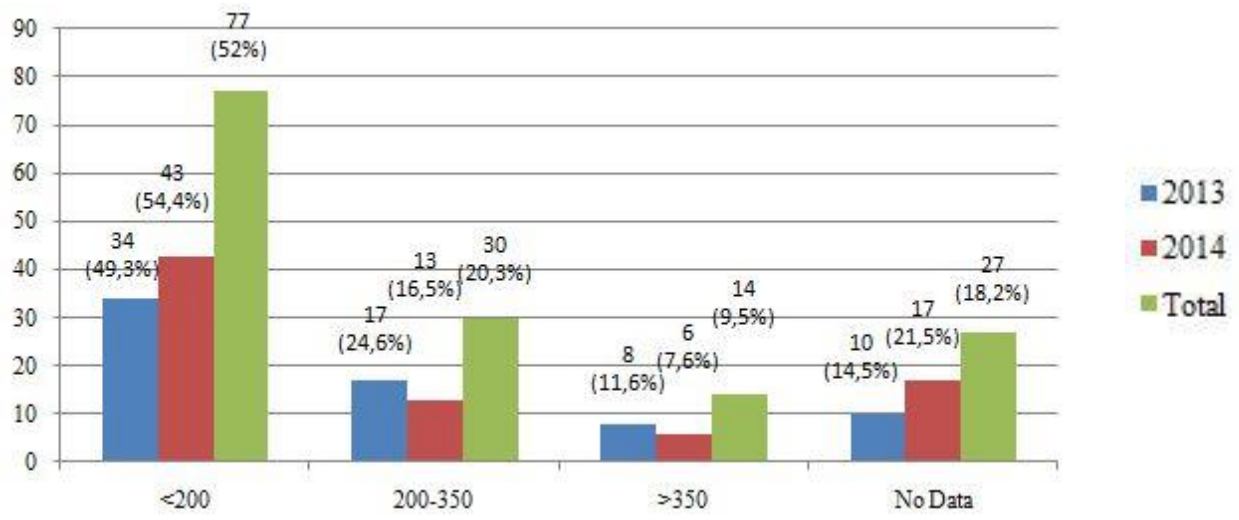

Figure 5: $\mathrm{CD}^{+}{ }^{+}$of STIs patients with HIV/AIDS

The appearance of new lesions in condylomata acuminate was associated with the cellular immunity of the patient. This was supported by research conducted by Sung and his colleagues that showed a higher prevalence of HPV infections, including anal condylomata acuminate in patients with ongoing immunosuppressant therapy and HIV infected patients. $\mathrm{CD}^{+}$is a very good indicator to measure the immune condition of HIV patients. The low number of CD4 ${ }^{+}$was found in patients with recurrent condylomata acuminate (Lacey et al., 2011). ARV therapy was given in UPIPI following WHO's recommendations which included in giving of tenofovir, lamivudine, and efavirenz. Management of STIs in patients with HIV/AIDS was equally necessary to overcome the disease in general by giving antiretroviral drugs to patients with HIV/AIDS; the incidence of STIs will become rarer.

No significant difference of number was found regarding the recovery between treated and untreated patients. It might be caused by the fact the patients were treated in many different outpatient clinics other than Dermatovenerology alone, therefore it was required patience in carrying outpatient therapies. The recurrence rates were also associated with HIV infection and AIDS, thus that condition will increase the recurrence (Rompalo et al., 2008, Workowski et al., 2008).

The limitation of this study was theuse of retrospective studies as astudy design. Furthermore, it requires further prospective cohort analytic study to confirm the correlation between HIV/AIDS and STIs. 


\section{Conclusion}

STIs and HIV/AIDS were closely related. HIV/AIDS could increase the incidence of STIs and vice-versa, the increasing of STIs could elevate HIV/AIDS. The age group with high sexual activity will be in high risk for STIs, especially in HIV patients. The $\mathrm{CD}^{+}$level was associated with increasing number of STIs in HIV patients.

Conflict Interest Statement: The authors of this work, hereby declares that there is no competing interest among them and that there are also no financial or professional affiliations with any group or company.

\section{References}

1. Abdulai, M.A., Baiden, F., Asiedu, S.A., Febir, L.G., Adjei, K.K., Mahama E., Agyemang, C.T., Newton, S.K., Asante, K.P., Aggyei, S.O. (2017). The risk of sexually transmitted infection and its influence on condom use among pregnant women in the Kintampo north municipality of Ghana. Journal of Sexually Transmitted Diseases. [cited March $10^{\text {th }}$ 2017]. Available at: https://doi.org/10.1155/2017/8642685.

2. Astindari, Lumintang, H. (2011). Cara penularan HIV \& AIDS di Unit Perawatan Intermediate Penyakit Infeksi (UPIPI) RSUD Dr. Soetomo Surabaya (thesis). Surabaya: Universitas Airlangga.

3. Buchacz, K., Patel, P.,Taylor, M., Kerndt, P.R., Byers, R.H., Holmberg, S.D., Klausner, J.D. (2004). Syphilis increases HIV viral load and decreases CD4 cell counts in HIV-infected patients with new syphilis infections. AIDS, 18 (15):2075-9.

4. Bunker, C.B., Gotch, F. (2010). HIV and the skin. In:Burns, T., Breathnach, S., Cox, N., Griffiths, C., editors. Rook's textbook of dermatology. $8^{\text {th }}$ ed. Oxford: Wiley-Blackwell; pp.35.1-41.

5. Chun, H.M., Carpenter, R.J., Macalino, G.E., Cianflone N.F. (2013). The role of sexually transmitted infections in HIV progression. Journal of Sexually Transmitted Diseases, 25 (2):1-16.

6. Dewi, I.S.L., Hidayati, A.N. (2015). Manifestation of Skin Disorders in HIV/AIDS. Berkala Ilmu Kesehatan Kulit dan Kelamin., 27 (2):97-105.

7. Direktorat Jendral Pencegahan dan Pengendalian Penyakit dan Penyehatan Lingkungan Kementrian Kesehatan Republik Indonesia (2014). Statistik kasus HIV/AIDS di Indonesia. Indonesia: Ditjen PP \& PL Kemenkes RI 2014 [cited 18 September 2014]. Available from: http://spiritia.or.id/Stats/StatCurr.pdf

8. Furtado, M.R., Callaway, D.S., Phair, J.P., Kunstman, K.J., Stanton, J.L., Macken, C.A., Parelson, A.S., Wolinsky, S.M. (1999). Persistence of HIV-1 transcription in peripheral-blood mononuclear cells in patients receiving potent anti retroviral therapy. The New England Journal of Medicine, 340:1614-22.

9. Goff, J., Péré, H., Bélec, L. (2014). Diagnosis of genital Herpes simplex virus infection in the clinical laboratory. Virology Journal, 11:83.

10. Hamish, M., Mitchell, H., Sile, B., Duffell, S., Nardone, A., Hughes, G. (2016). Increase in sexually transmitted infections among men who have sex with men. Emerging Infectious Diseases Journal, 22(1):88-91.

11. Lacey, C., Woodhall, S., Wilkstrom, A., Ross, J. (2011). European guideline for the management of anogenital warts. IUSTI. GW Guidelines. 7:1-20.

12. Moir, S., Chun, T.W., Fauci, A.S. (2011). Immunology and pathogenesis of Human immunodeficiency virus infection. Annual Reviewof Pathology, 6:223-48.

13. Nasronudin. (2014). Transmisi infeksi HIV. Dalam: Barakbah, J., Soewandojo, E., Suharto, Hadi, U., Astuti, D., Bramantono., et al, editors. HIV dan AIDS. Pendekatan biologi molekuler, klinis, dan sosial. Surabaya: Airlangga University Press. pp. 21-4.

14. Nelwan, S.R., Niode, N.J., Kapantow, M.G. (2012). Profil kondiloma akuminata di Poliklinik Kulit dan Kelamin RSUP Prof. Dr. Kandou Manado periode Januari 2012-Desember 2012. Bagian/SMF Kulit dan kelamin RSUP Prof. Dr. R.D Kandou Manado.[cited Maret $10^{\text {th }}$ 2015]. Availablefrom: http://download.portalgaruda.org/article.php?article $=146260 \& v a l=1001$

15. Ochom, J.A., Mannan, H., Groce, N.E., Veigh, J.M. (2017). HIV/AIDS knowledge, attitudes and behaviour of persons with and without disabilities from the Uganda demographic and health survey 2011: differential access to HIV/AIDS information and services. Plos one., 12:4.

16. Quader, A.A., Berry, M., Bingham, T., Burnett, J., Dong, M., Drake, A., Hakim, A., Hladik, W., Marandet, A., Mclntyre, A., Murrill, C., Neal, J., Patel, N. (2017). Bio behavioural survey guidlines for populations at risk for HIV. Geneva: World Health Organization.

17. UNICEF Indonesia (2012). Respons terhadap HIV dan AIDS. Indonesia: UNICEF Indonesia. Ringkasan Kajian (Internet) 2012 [cited September 18 2014]. Available from: http://www.unicef.org/indonesia/id/A4_B Ringkasan_Kajian_HIV.pdf

18. Rompalo, A.M., Quinn, T.C. (2008). Sexually transmitted intestinal syndrome. Management of dermatologic and 
extragenital manifestation of STD and HIV infections. In: Holmes, K.K., Sparling, P.F., Wasserheit, J., Stamm, W., Piot, P., Corey, L., et al, editors. Sexually transmitted disease $4^{\text {th }}$ ed. New York: McGraw - Hill. pp. 1277-308.

19. Tzeng, J., Clark, L., Garges, E., Otto, J. (2013). Epidemiology of sexually transmitted infections among Human immunodeficiency virus positive United States military personnel. Journal of Sexually Transmitted Diseases: 1-9

20. UNAIDS. (2012). The gap report. Jenewa: UNAIDS (online) 201 [cited March $1{ }^{\text {st }}$ 2015]. Availablefrom:http://www.unaids.org/en/media/unaids/contentassets/documents/epidemiology/2012/gr2012/20121 120_UNAIDS_Global_Report_2012_en.pdf.

21. Uihlein, L., Saavedra, A. P., Johnson, R. A. (2012). Cutaneous manifestations of Human immunedeficiency virus disease. In: Goldsmith, L.A., Katz, S.I., Gilchrest, B.A., Paller, A.S., Leffel, D.J., Wolff, K., editors. Fitzpatrick's dermatology in general medicine. $8^{\text {th }}$ ed. New York: The Mc Graw-Hill Companies; pp. 4574-5.

22. Workowski, K., Berman, S. (2008). Sexually transmitted diseases treatment guidelines. In: Holmes, K.K., Sparling, P.F., Wasserheit, J., Stamm, W., Piot, P., Corey, L., et al, editors. Sexually transmitted disease. $4^{\text {th }}$ ed. New York: The McGraw-Hill Companies; p.2089-114.

23. Xhilaga, M.S. (2006). Basic HIV virology. In: VIC Robert Oelrichs. Global HIV/AIDS program. Washington: The World Bank; pp. 6-10. 